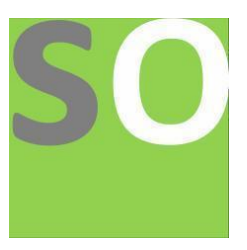

Article title: Cultural Influences on Traditional and Modern Architecture in ljebu-Ode

Authors: Kayode Olatunji Kazeem[1], Ayodele Emmanuel Ikudayisi[2], Oluwatobi Gbenga Adelakun[3]

Affiliations: Department of Architecture, Federal University of Technology Akure, Ondo State, Nigeria[1], Department of Metallurgy and Materials Engineering, Federal University of Technology Akure, Ondo State, Nigeria[2]

Orcid ids: 0000-0002-9175-729X[1]

Contact e-mail: josephubooks@gmail.com

License information: This work has been published open access under Creative Commons Attribution License http://creativecommons.org/licenses/by/4.0/, which permits unrestricted use, distribution, and reproduction in any medium, provided the original work is properly cited. Conditions, terms of use and publishing policy can be found at https://www.scienceopen.com/.

Preprint statement: This article is a preprint and has not been peer-reviewed, under consideration and submitted to ScienceOpen Preprints for open peer review.

DOI: 10.14293/S2199-1006.1.SOR-.PPUOYFD.v1

Preprint first posted online: 20 March 2021

Keywords: Architecture, Building, Culture, Modern, Traditional 


\title{
Cultural Influences on Traditional and Modern Architecture in Ijebu-Ode
}

\author{
Kayode Olatunji Kazeem, Ayodele Emmanuel Ikudayisi, Oluwatobi Gbenga Adelakun \\ Department of Architecture, Federal University of Technology Akure, Nigeria
}

\begin{abstract}
Technology, available materials, economy, culture and host of other factors influence man's dwelling and play important roles in determining the type of building he inhabits. However, little research has been carried out in order to determine the influences of culture on both traditional and modern architecture in Nigeria. The aim of this research project, therefore, is to determine and compare the influences of culture on the traditional and modern building types in Nigeria using Ijebu-Ode as a case study. Questionnaires were randomly administered both in Ita-Alapo and Obalende representing traditional and modern areas of the town respectively. Also, building typologies were randomly selected in both areas and were compared in terms of building quality, form and techniques. The results gathered were then analyzed descriptively with the use of tables and charts showing their frequencies, mean and rank. The analysis revealed that while security was the first factor that influences the types of building in the modern area (Obalende), it was the people's family structure that determines their building type in the traditional area (Ita-Alapo). The research concluded by recommending that Nigerian architects should always endeavor to consider and incorporate the people's culture into their designs, especially when designing where they will live.
\end{abstract}

Keywords: Architecture, Building, Culture, Modern, Traditional

\section{INTRODUCTION}

$\mathrm{M}$ an's first house was determined by his intention to get sheltered from the inclement and dangerous conditions of his environment. Subsequently, other factors such as technology, available materials and economy also began to affect his quest for shelter. In fact, [1] concluded that in architecture, people build on the basis of four conditions:

- Climate

- Technology

- Material

- Economy

This fact tallies with the picture painted by [2] that as architecture developed, the concept of the shelter was extended from simple physical protection from cold, dampness, wind and sun toward an increasingly complex set of cultural traits centered around the growing idea of the family home. In the same vein, [3] reported that in the past, the tribal, racial and ethnic differences, distances, class borders, climate, land, religions had effects on architecture and it resulted in forming different patterns of life styles, living space, invocation buildings and also residences.
Architecture always follows certain known rules and regulations and has a strong and unbreakable bond with the culture, values and behavior patterns of any society [4]. This is why the architectural style of each period is a reflection of the culture and art of that period. Consequent to this, a selected set of cultural aspects will be studied which have been found most likely to influence architectural form. These aspects of culture will then be utilized in the study of various works of traditional and modern architecture of Ijebu-Ode.

The architecture of each era has a direct relationship with its culture and art, also, different thoughts create different architecture and styles. Architecture pays attention to people's cultural needs. Architecture and indeed, the house, is often regarded and thus described as an encapsulation of the cultural heritage of a people [5].

Meanwhile, [6] sees the idea of housing as an objective of fulfilling one of the basic needs of man principally in the provision of shelter, and comfort. In the practical establishment of homes, the planning and construction takes a pattern or form, which varies from society to society and country. Consequently, the form of housing chosen or built offers a direct insight into the study of various culture and societies of the people.

In the same vein, [7], in one of his public lectures, concluded that amidst the paradox of fostering traditional values and of growth and change lie possibilities for a better life and lasting qualities of an enduring Architecture. The reason for this research is, thus, to examine this significant aspect - culture; whereby useful aspects of traditional architecture are incorporated into modern architecture for the purpose of improving the standard of living environmental conditions of the contemporary people of Ijebu-Ode, Nigeria.

\section{LITERATURE REVIEW}

According to [8] culture originates from the term 'cultivation', implying that one has grown through knowledge or experience. Culture may further be defined as behavior peculiar to Homo sapiens, together with material objects used as an integral part of his behavior, specifically culture consists of language, ideas beliefs, customs, codes, institutions, and so on. As a cultural system, isolated quantitative relationships between different aspects of culture become less important than the qualitative relationships within the overall system [8] . Furthermore, [2] held that each tradition is comprised of loosely correlated aesthetic, social, economic, political and 
ethical codes of behavior and members variably share ideologies, habits, customs, procedures and technologies.

Meanwhile, man over time evolved ways of tackling issues including cultural issues, and he has since left his simple, crude and sedentary kind of life about a thousand years ago for a vibrant, dynamic and sophisticated one through the use of his intellect for the slow but purposeful movement [9].

Architecture is building according to mental formats and the architectural form and system of each region is affected by its " cultural environment. Architecture and indeed, the house, is often regarded and thus described as an encapsulation of the cultural heritage of a people [5]. All over the world, culture, as noted by [10] is "the major determinant of the settlement pattern of any group of people." In his research on culture and housing, [1]-[11] described architecture as a profession rooted in culture and that spatial and social relations are not random, but ordered. African architecture has been in place as far as the time when Africa has been in existence. In one of his books, [12] stated that each nation which has built its own architecture, has expressed its own forms of language, traditions and habits. However, [1] describes traditional architecture as changing values and it is also the picture of home and world view and life style and a combination of different situations. In his view, traditional architecture tries to create a balance with nature instead of dominate it and he considers this factor as the factor of superiority of this architecture in comparison with stylistic ones in terms of the relationship between human made environment and nature.

The Yoruba traditional architecture is characterized by multicell, rectilinear compound houses, with multiple impluviumcourtyards and that of Ijebu-Ode is not an exception [13]. Another major accessory of the traditional Yoruba built form was the palm-tree. Palm fronds were used together with broad gbodogi (sarcophrynium) leaves, for cladding purposes, and the stem was cut up and used as trusses and purlins on the roof framework [14]. There has also been the introduction of fascia boards in the roof structure. Even today, paint render is still optional - more a reflection of economic realities than aesthetic indifference [13].

\section{RESEARCH METHODS}

1) Sample Frame and Size: The sampling frame is a list of all those within the population who can be sampled and this includes individuals that have secured houses for themselves and their families in Ita-alapo and Obalende area of IjebuOde, Ogun state, Nigeria. To obtain data from the whole population under investigation may be practically impossible considering time and cost. Therefore, the sample size of respondents for this study is thirty from area with traditional housing and thirty from their modern counterpart. This summed up to sixty (60) respondents in all.

2) Sample Technique and Data Collection Instruments: The sampling technique adopted for this study is the stratified random sampling technique. Stratified random sampling, according to explorable.com, is a probability sampling technique wherein the researcher divides the entire population into different subgroups or strata, then randomly selects the final subjects proportionally from the different strata. This technique is useful in this research because it ensures the presence of the key subgroup within the whole sample frame. The sampling frame for this study was grouped into two: house owners in traditional and modern housing environments. The instruments for data collection included:

Well-structured questionnaires.

Oral interview with the respondents and Olotun (community head) of Ita-alapo, Ijebu-Ode.

\section{- Case study of typologies.}

The questionnaire was framed in three sections, each section in the questionnaire was designed to measure a specific aspect of the set objectives. The first section was designed to collect general information about the respondents, such as gender, age, educational qualification, family type, occupation, social status, to mention but a few. This is to check for the quality of the data that will be subsequently acquired from the respondents before embarking on statistical analysis. Furthermore, the second section was designed to assess aspects that involve building quality, building materials, and design and construction techniques in the research.

Finally, the third section was framed such that it will address the extent in which culture has, in one way or the other, affected people's building type in Ijebu-Ode. The question was rated on a 5-points scale ranging from 'to a great extent' to 'not at all'.

The questionnaires were self-administered through direct contact with respondent. The respondents were given the questionnaires to fill with some assistance from the researcher in situations whereby the questions seemed unclear to the respondents. Also, aerial pictures were taken and two typologies were made from both traditional and modern housing environments. The statistical analysis of data was carried out with the aid of statistical package for social sciences (SPSS). The data collected were presented in tables and charts.

3) Questionnaire Design: This section discusses the case study of housing typologies carried out in Ita-alapo and Obalende area of Ijebu-Ode representing the traditional and modern housing communities respectively. It also discusses the analysis of responses collected through the use of questionnaires. A three-section questionnaire was administered with few and concise words that introduce the purpose of the questionnaire to the respondents and also solicit for their sincere responses. The design of the questionnaire was such that it conveniently and effectively sourced useful information from the respondents as far as this research is concerned. The sub-sections in the questionnaire include information on the respondent's characteristics; housing information, such as the tenure system of the respondent; respondent's housing quality, building design and 
materials; cultural influences on their housing types and the adequacy level of basic infrastructural facilities in their community. The sample size of 70 was used of which 60 questionnaires were retrieved and found suitable for analysis. The statistical analysis of data was carried out with the aid of statistical package for social sciences (SPSS). The data collected were presented in tables and charts and the results were later discussed. The respondents are thirty dwellers in Ita-Alapo and Obalende areas of Ijebu-Ode. They were randomly selected during the field work of this research.

\section{DISCUSSION AND FINDINGS}

Table I: Characteristics of Respondents

\begin{tabular}{|c|c|c|c|c|}
\hline \multicolumn{2}{|c|}{ Characteristics } & Ita-Alapo & Obalende & Total \\
\hline Gender & $\begin{array}{c}\text { Male } \\
\text { Female }\end{array}$ & $\begin{array}{c}24 \\
6\end{array}$ & $\begin{array}{c}21 \\
9\end{array}$ & 60 \\
\hline
\end{tabular}

\begin{tabular}{|c|c|c|c|c|}
\hline Qualification & None & 10 & 1 & 60 \\
& Primary & 5 & 1 & \\
& Secondary & 9 & 8 & \\
& Degree & 6 & 20 & \\
\hline
\end{tabular}

\begin{tabular}{|c|c|c|c|c|}
\hline Age group & $20-30$ & 5 & 14 & 60 \\
& $31-40$ & 4 & 7 & \\
& $41-50$ & 1 & 3 & \\
& $51-60$ & 9 & 2 & \\
& Above 60 & 11 & 4 & \\
\hline
\end{tabular}

\begin{tabular}{|c|c|c|c|c|}
\hline Marital status & Single & 5 & 13 & 60 \\
& Married & 20 & 17 & \\
& Widow(er) & 5 & & \\
\hline
\end{tabular}

\begin{tabular}{|c|c|c|c|c|}
\hline Family type & Monogamy & 19 & 20 & 60 \\
& Polygamy & 11 & 7 & \\
& Others & & 3 & \\
\hline
\end{tabular}

\begin{tabular}{|l|c|c|c|c|}
\hline Occupation & Trader & 12 & 7 & 60 \\
& Civil-servant & 2 & 10 & \\
& Farmer & & & \\
& Artisan & 4 & 3 & \\
& Retired & 5 & 3 & \\
& Others & 4 & 2 & \\
& & 3 & 5 & \\
\hline
\end{tabular}

\begin{tabular}{|c|c|c|c|c|}
\hline Ethnicity & Yoruba & 30 & 27 & 60 \\
& Hausa & & 1 & \\
& Igbo & & 1 & \\
& Others & & 1 & \\
\hline
\end{tabular}

Table I showed the general characteristics of respondents. In the traditional area of the study, $80 \%$ of the respondents were male while $20 \%$ of the total respondents were female. In the same vein, from Table I above, whereas $70 \%$ of the total respondents living in modern area were male, $30 \%$ were female. Also, it can be deduced that majority of the respondent in the traditional area are traders while most of the respondents in the modern area are civil servants. The table also compares the religion, ethnicity, social status, the age group, among others of the respondents.
BUILDING QUALITY IN ITA-ALAPO

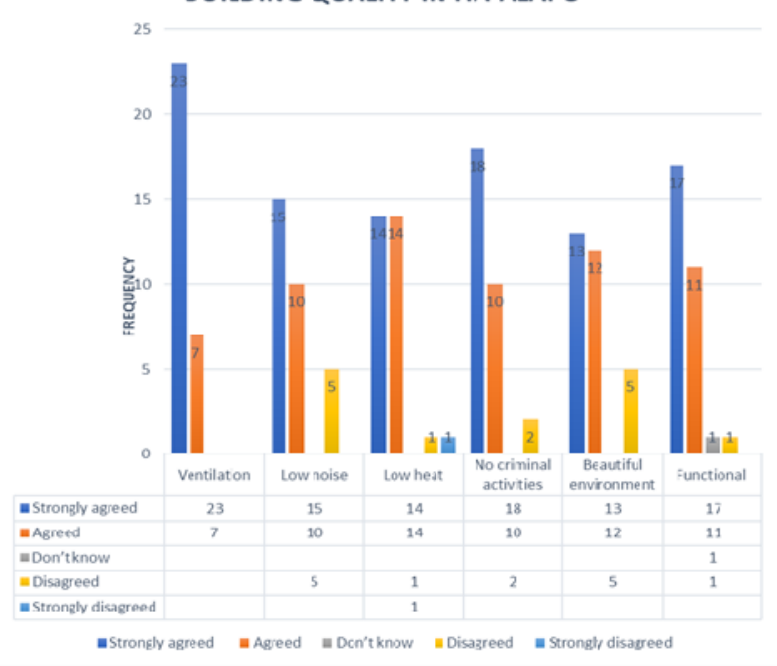

Fig. 1 Building quality in Ita-Alapo

From Fig. 1 above, it can be deduced that most of the respondents in Ita-Alapo strongly attested to the fact that there is adequate ventilation, low noise level, low level of heat in their houses; few cases of criminal activities in their neighborhood; their environment is well designed to the sight and that they have functional spaces in their houses. In the same vein, Fig. 2 below shows that most of the respondents either strongly agreed or agreed to the fact that there is adequate ventilation, low level of noise pollution, low heat level, low level of criminal activities in their places of abode and that their buildings and environment are well designed. It is important to note, from both figure 1 and 2 that few numbers of respondents disagreed to the fact that there is adequate ventilation, low level of noise pollution, low heat level, low level of criminal activities in their places of abode and that their buildings and environment are well designed.

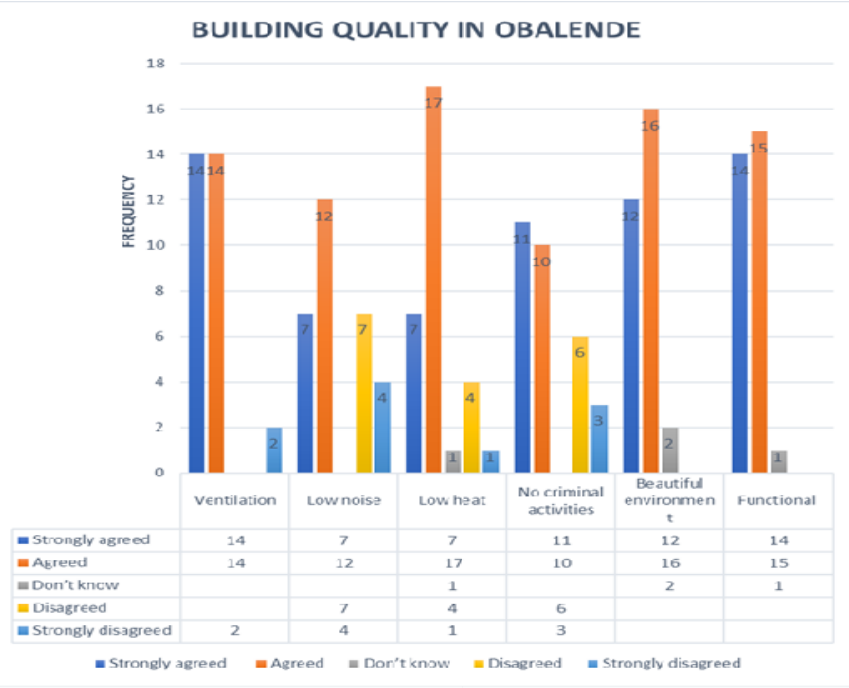

Fig. 2 Building quality in Obalende 
Table II: Building and Building Materials Information

\begin{tabular}{|c|c|c|c|}
\hline & & Ita-Alapo & Obalende \\
\hline Type & $\begin{array}{l}\text { Single family } \\
\text { Multi family } \\
\text { Rooming } \\
\text { Compound }\end{array}$ & $\begin{array}{c}3 \\
4 \\
10 \\
13\end{array}$ & $\begin{array}{c}12 \\
16 \\
2\end{array}$ \\
\hline Occupants & $\begin{array}{c}1-3 \\
4-6 \\
7-10 \\
11-20 \\
\text { Above } 20\end{array}$ & $\begin{array}{c}1 \\
6 \\
5 \\
11 \\
7 \\
\end{array}$ & $\begin{array}{c}6 \\
13 \\
5 \\
4 \\
2 \\
\end{array}$ \\
\hline Tenure & $\begin{array}{c}\text { Rented } \\
\text { Personal } \\
\text { Free-house } \\
\text { Family house }\end{array}$ & $\begin{array}{c}4 \\
11 \\
1 \\
14 \\
\end{array}$ & $\begin{array}{c}7 \\
19 \\
1 \\
3 \\
\end{array}$ \\
\hline Population & $\begin{array}{c}\text { High } \\
\text { Average } \\
\text { Low }\end{array}$ & $\begin{array}{c}12 \\
15 \\
3\end{array}$ & $\begin{array}{c}11 \\
16 \\
3\end{array}$ \\
\hline Wall & $\begin{array}{c}\text { Laterite } \\
\text { Sandcrete } \\
\text { Mold brick }\end{array}$ & $\begin{array}{c}9 \\
12 \\
9\end{array}$ & $\begin{array}{c}2 \\
27 \\
1\end{array}$ \\
\hline Floor & $\begin{array}{l}\text { Concrete } \\
\text { Steel } \\
\text { Timber }\end{array}$ & 30 & $\begin{array}{c}28 \\
1 \\
1\end{array}$ \\
\hline $\begin{array}{c}\text { Foundatio } \\
n\end{array}$ & $\begin{array}{c}\text { Laterite } \\
\text { Concrete }\end{array}$ & $\begin{array}{c}4 \\
26 \\
\end{array}$ & $\begin{array}{c}1 \\
29\end{array}$ \\
\hline Ceiling & $\begin{array}{c}\text { Mat } \\
\text { Timber slate } \\
\text { Asbestos } \\
\text { PVC } \\
\text { POP } \\
\text { Others }\end{array}$ & $\begin{array}{c}1 \\
9 \\
19 \\
1\end{array}$ & $\begin{array}{c}1 \\
3 \\
17 \\
5 \\
3 \\
1\end{array}$ \\
\hline Door & $\begin{array}{l}\text { Timber } \\
\text { Metal } \\
\text { Glass }\end{array}$ & $\begin{array}{c}27 \\
3\end{array}$ & $\begin{array}{c}13 \\
11 \\
6\end{array}$ \\
\hline Window & $\begin{array}{l}\text { Timber } \\
\text { Metal } \\
\text { Plastic } \\
\text { Glass }\end{array}$ & 22 & $\begin{array}{c}3 \\
6 \\
1 \\
20\end{array}$ \\
\hline Form & $\begin{array}{l}\text { Rectangular } \\
\text { Square }\end{array}$ & $\begin{array}{c}26 \\
4\end{array}$ & $\begin{array}{c}22 \\
8\end{array}$ \\
\hline Finance & $\begin{array}{c}\text { Personal } \\
\text { Community } \\
\text { Government } \\
\text { Others }\end{array}$ & $\begin{array}{c}17 \\
11 \\
1 \\
1\end{array}$ & $\begin{array}{c}26 \\
1 \\
2 \\
1\end{array}$ \\
\hline
\end{tabular}

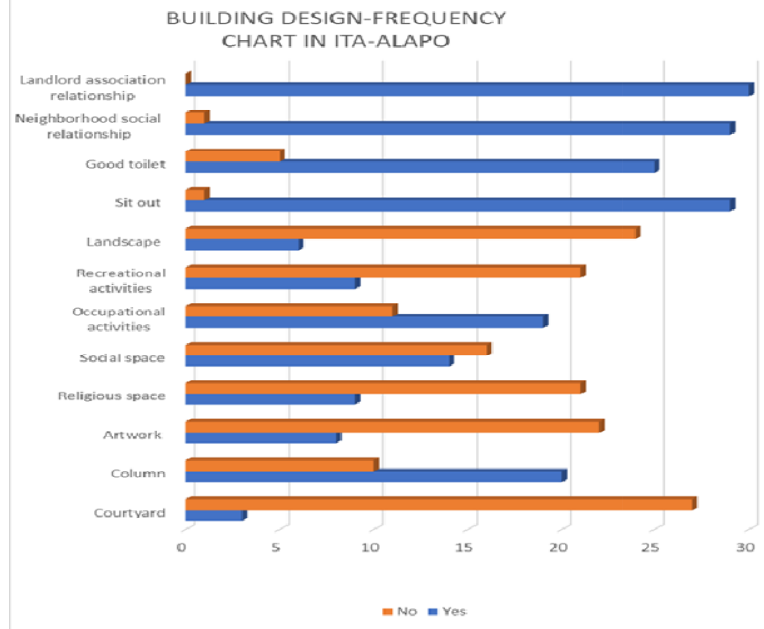

Fig. 3 Building design frequency chart in Ita- Alapo

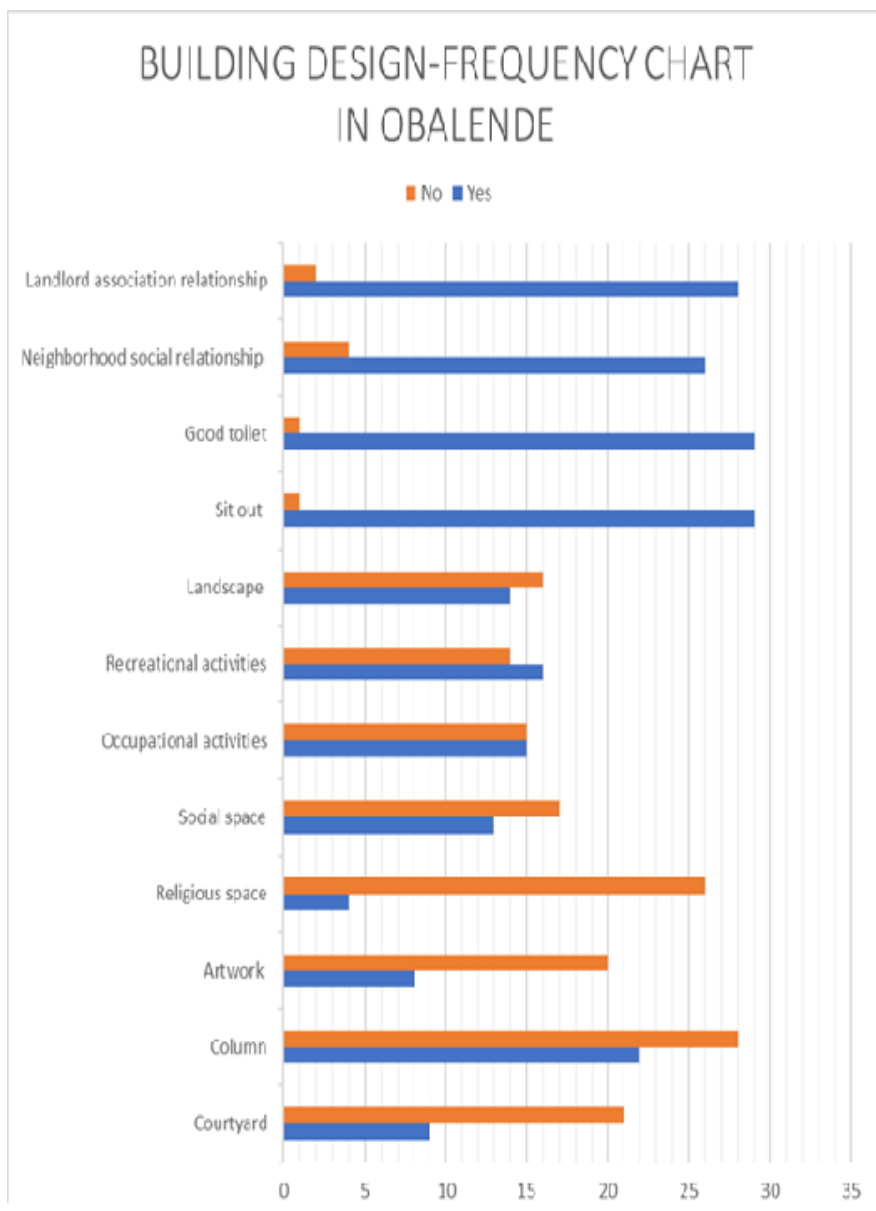

Fig. 4 Building design frequency chart in Obalende

From Table II, the rooming housing system (popularly called: face-me-and-face-you) is predominant in Obalende whereas, the compound housing system (agbo-ile) is more pronounced in Ita-alapo, the traditional area. Meanwhile, fig. 3 reveals that the utmost consideration is given to the provision of sit-outs and the availability of adequate conveniences even within the buildings. Also, it is crystal clear, from fig. 3 and 4 that most of the respondents cherish the efficacy of living in harmony and having a good social relationship within the neighborhood. Thus, they embrace a functional social relationship among themselves. It can also be deduced that most of the respondents considered the structural stability of their buildings by considering the use of columns in their building designs.

Table III: Cultural Influences Ranking In Ita-Alapo And Obalende, Ijebu-Ode

\begin{tabular}{|c|c|c|c|c|}
\hline \multirow{2}{*}{ Cultural Influences } & \multicolumn{2}{|c|}{$\begin{array}{c}\text { Ita-Alapo } \\
\text { (Traditional) }\end{array}$} & \multicolumn{2}{c|}{$\begin{array}{c}\text { Obalende } \\
\text { (Modern) }\end{array}$} \\
\cline { 2 - 5 } & Mean & Rank & Mean & Rank \\
\hline Family Structure & 4.77 & $1^{\text {st }}$ & 4.30 & $2^{\text {nd }}$ \\
\hline Income & 4.07 & $2^{\text {nd }}$ & 3.67 & $3^{\text {rd }}$ \\
\hline
\end{tabular}




\begin{tabular}{|c|c|c|c|c|}
\hline Security & 3.97 & $3^{\text {rd }}$ & 4.70 & $1^{\text {st }}$ \\
\hline Social & 3.80 & $4^{\text {th }}$ & 3.60 & $4^{\text {th }}$ \\
\hline Occupation & 3.63 & $5^{\text {th }}$ & 3.33 & $6^{\text {th }}$ \\
\hline Religious & 3.60 & $6^{\text {th }}$ & 3.27 & $7^{\text {th }}$ \\
\hline Ceremonial & 3.43 & $7^{\text {th }}$ & 2.63 & $8^{\text {th }}$ \\
\hline Educational & 2.93 & $8^{\text {th }}$ & 3.45 & $5^{\text {th }}$ \\
\hline
\end{tabular}

From Table III, respondents in Ita-Alapo are of the opinion that their family structure is what mostly determines their building type and design. Also, they believed that another important aspect of their culture that influenced their type of architecture is their income level, and so, they must be industrious and work in order to get the wherewithal to achieving their goal. In the same vein, they consider the aspect of security much in their building design. This is probably as a result of the present security state of the country. More so, at the bottom of the table are aspect of culture such as education that seemed less relevant to the respondents as far as their architecture is concerned. In Obalende, the aspects of culture that greatly affect their architecture are security, family structure and their income level. Meanwhile other aspects such as their religion and the need for ceremony, though have a say in their type of architecture, only have a little effect on their architecture.

\section{A. Case Study}

The case study was conducted in different locations representing the traditional and modern areas of Ijebu-Ode. The locations were: Ita-Alapo and Obalende. Both locations are in Ijebu-Ode Local Government Area of the Ijebu-Ode town. Whereas Ita-Alapo is a typical traditional area where various forms of traditional building types can be found, Obalende is a developing community where modern housing designs are prominent. Also, it is important to note that although Ita-Alapo, in this research, represents the traditional community where traditional housing type can be found, there are, however, modern housing types at the fringe of this area. The reason for this case study is to compare cultural influences on traditional and modern housing in Ijebu-Ode.

1) Typology One: The building is located at Ita-Alapo area of Ijebu-Ode. It is a typical traditional family dwelling with five rooms that serve as bedrooms for three set of peoplethe husband, wives and the children. The kitchen and the convenience are detached from the main building and are located at the back yard or the open space at the rare of the building. Whereas, the household shrine is being shared by two adjacent households which are relatives.

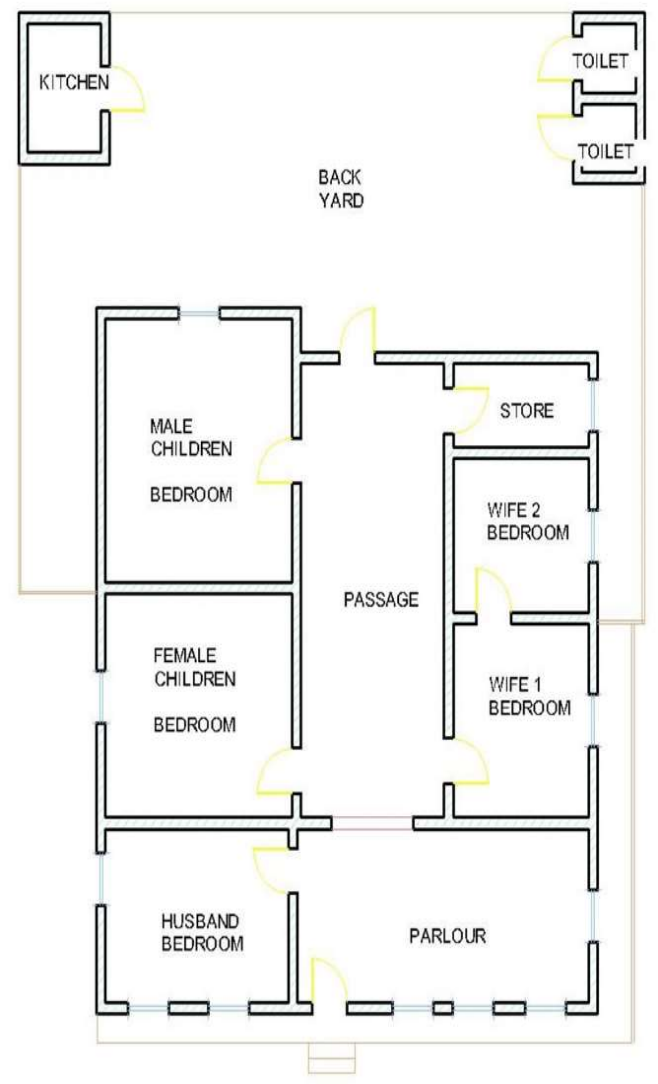

Fig. 5 Floor plan of typology one

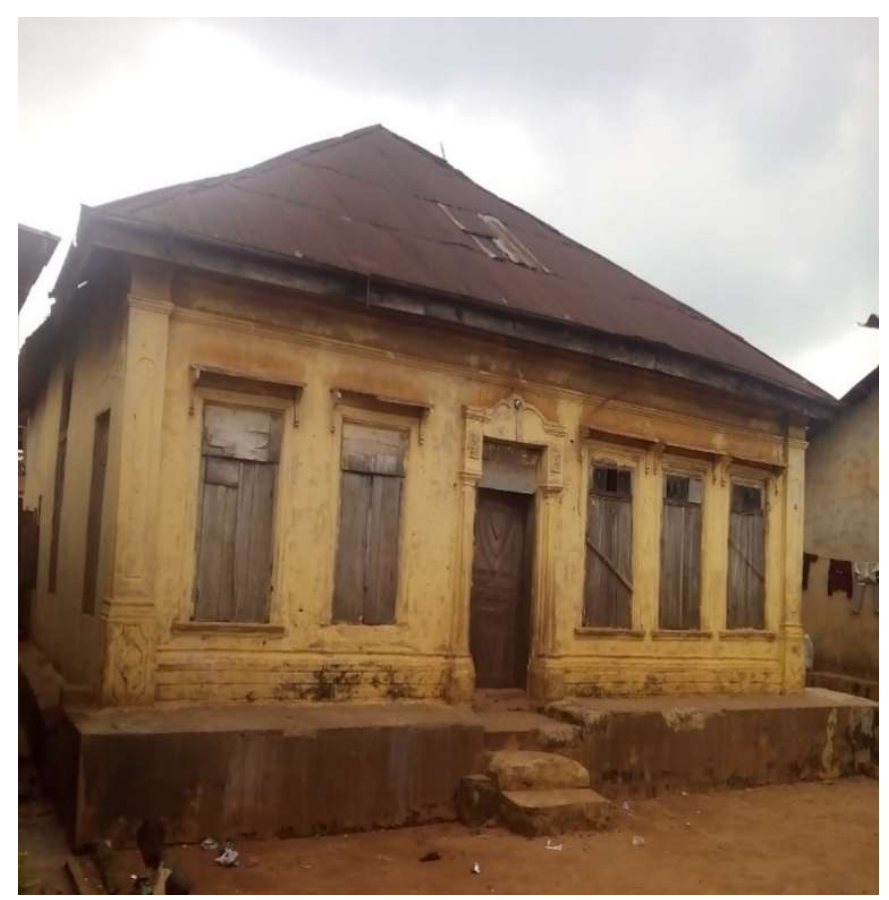

Fig. 6 The approach view of typology one 


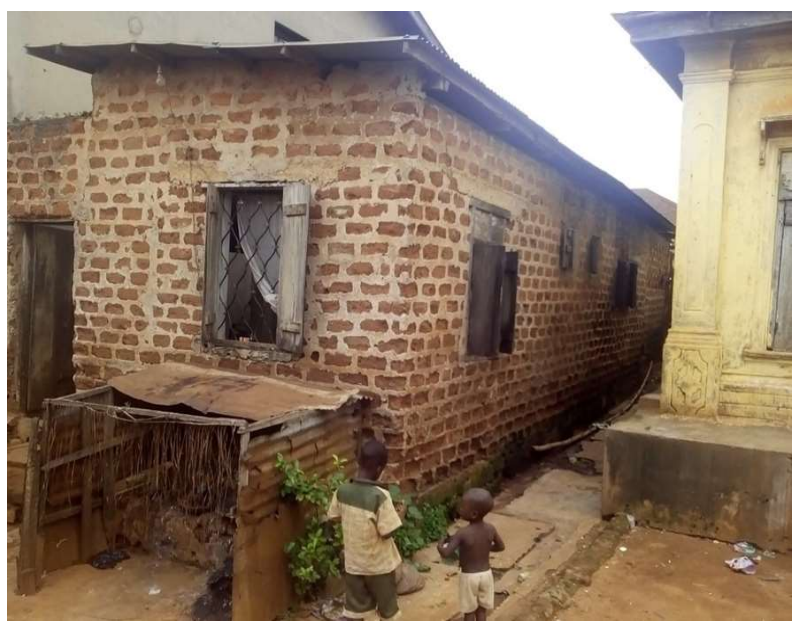

Fig. 7 Image of a typical household shrine located at the approach of adjacent buildings

2) Typology Two: The building is located at Ita-Alapo area of Ijebu-Ode. It is a typical traditional rooming housing (face-to-face) with different units demarcated by courtyards. It can be referred to, as a matter of fact, a typical, traditional Yoruba compound dwelling. One of the units in the compound dwelling has seven bedrooms and a living room summing up to eight rooms altogether. Larger percentages of the rooms are occupied by tenants while the living room and the room beside it are occupied by someone who is supposed to be a descendant of the house owner. Like the first typology, the cooking area and the conveniences are detached from the main building and are situated somewhere within the rare of the compound. The space for the kitchen, or better still, the cooking area, unlike the conveniences, is opened and merely defined by a timber shed covered with a thatch roof.

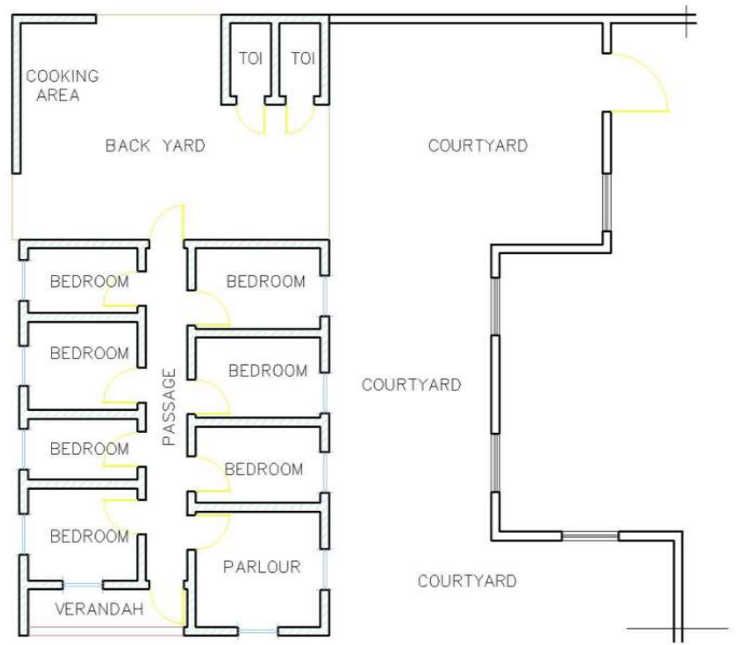

Fig. 8 Floor plan of typology two

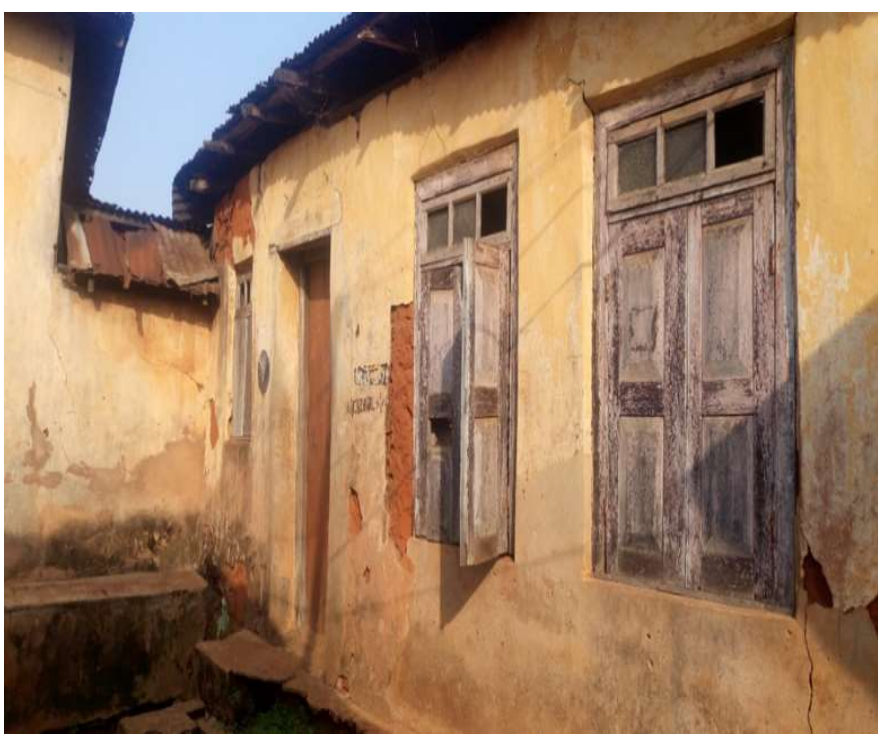

Fig. 9 Image of typology two from the side view

3) modern area of the study. This residential apartment is a storeyed building with typical three bedroom flat on each of the two floors. A close look at the space arrangement will quickly suggests that the building is an advanced rooming housing. The reason for this kind of design is to cater for the family structure of the owner; an apartment that will accommodate the household, and at the same time, exhibits or reflects an element of modernity. This can be deduced from the fact that the spaces for store, kitchen and conveniences, unlike the previously studied typologies, are incorporated with, and are not being secluded from the main building. Apart from this, one can conclude that the design is modern in that it catered, though not in an elaborated way, for the space required for the family dining. Typology Two: The building is located at the

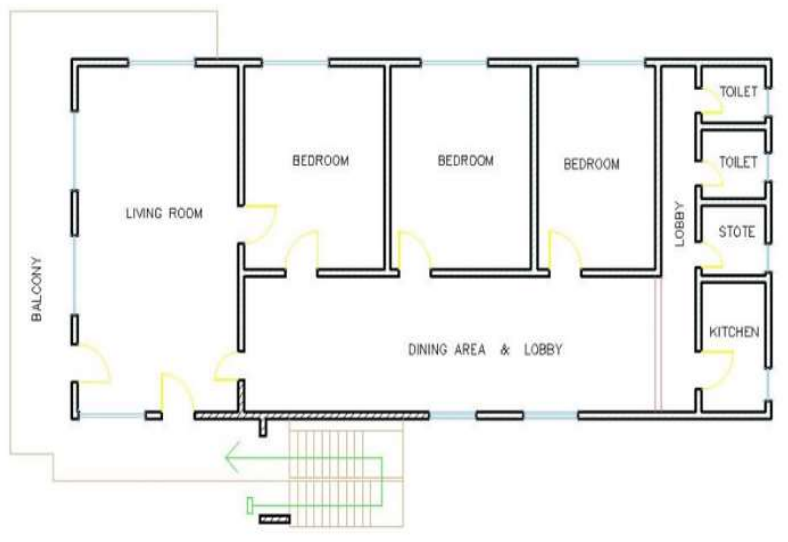

Fig. 10 Floor plan of typology three 


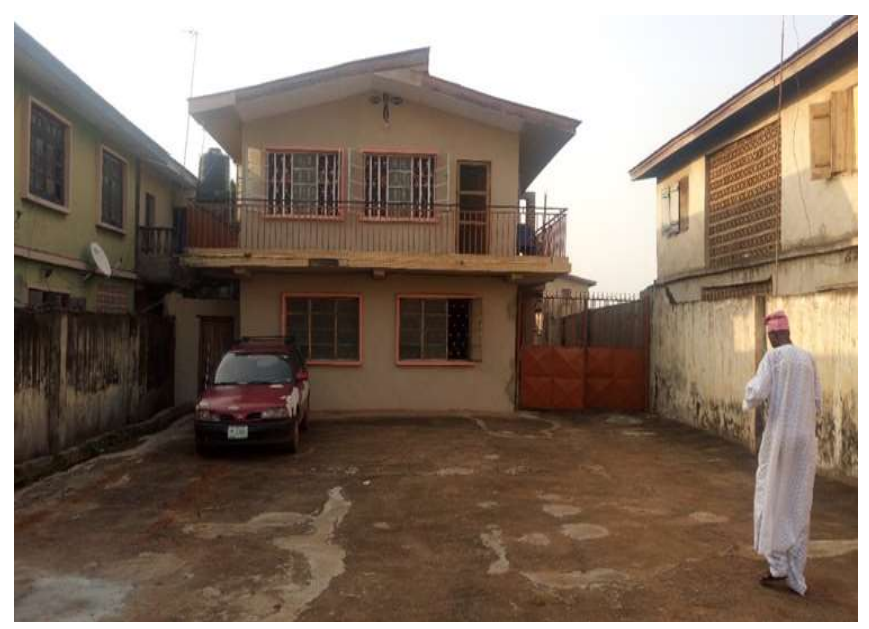

Fig. 11 Image showing the approach view of typology three

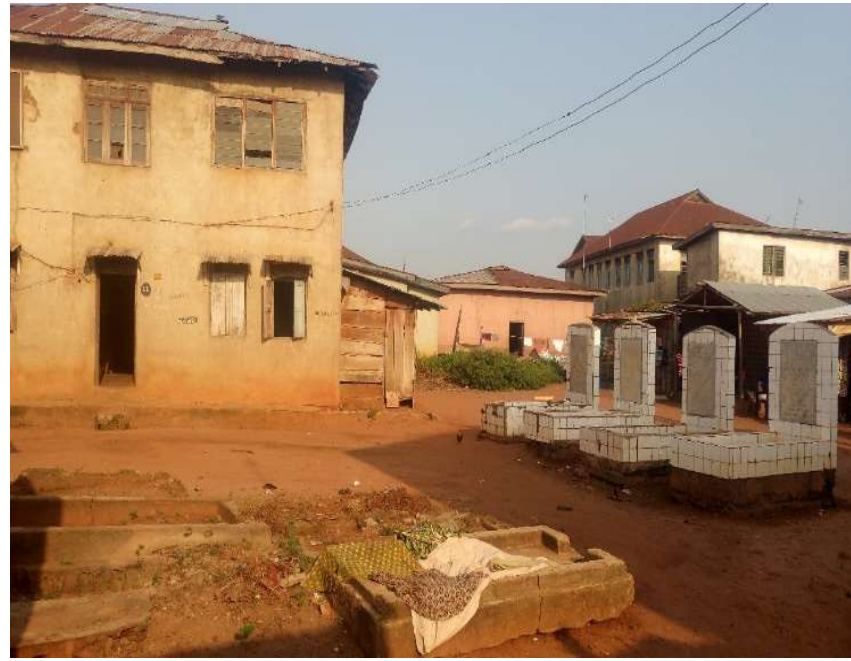

Fig. 12 Image showing a typical traditional compound dwelling with communal burial ground

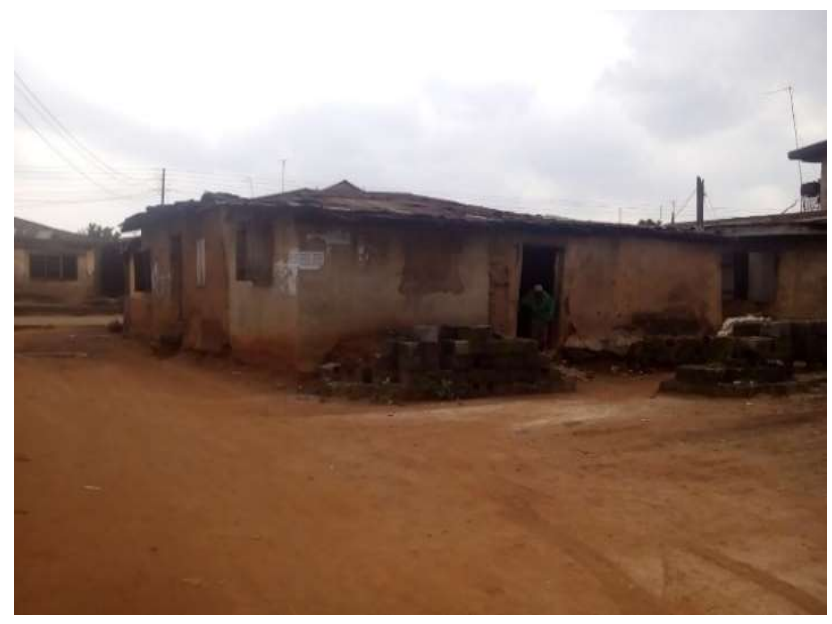

Fig. 13: Image showing an open space in Ita-Alapo

\section{B. Appendix}

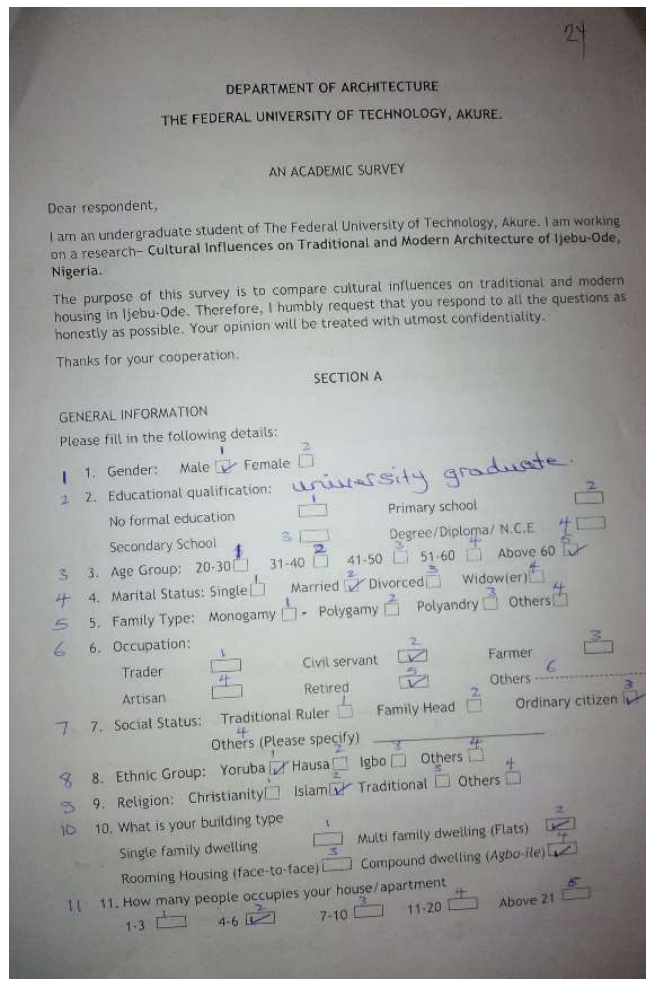

Fig. 14: Image showing the first page of the research questionnaire

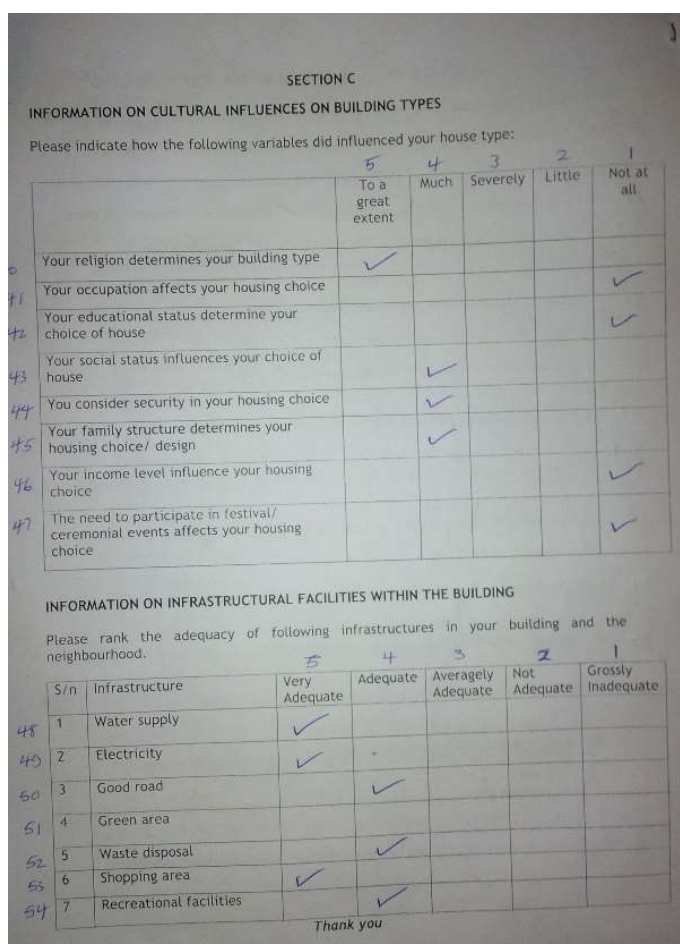

Fig. 15: Image showing the last page of the research questionnaire 


\section{CONCLUSION}

This paper has concisely looked into what culture is. It has established the fact that every group of people, either few or many, has their own culture and tradition and these cultural traits go a long way in determining their every-day lives; their daily activities - the way they think, react to spaces, the number of children they want to raise (which define their family structure), to mention but a few. All these as well determine, in return, the type of house they live in or will want to live in if they dare have one. It will yield good results if architects begin to consider culture in their various architectural developments, as far as Ijebu-ode and the whole of Nigeria is concerned.

While it is obvious that architects, designers and government policies in Nigeria have frivolously abandoned the traditional architecture lately, and little attention focuses on linking the Nigerian traditional architecture with modern architecture [15], architects and designers should nevertheless pursue to discover and revive what are the peculiar, specific and exclusive traits of a particular community, group of people or individuals from the inception of the design task; say at the stage of brief conception and development, and then find a way, by all means, to incorporate, integrate these subsisting traits appropriately in the concept, design and development of such projects. This will better the lives of the users and also make the built environment a better place to live for all and sundry.

Similarly, as designers of the built environment, architects should consider, but should not be limited to the particular building design in question, but also extend their horizon in terms of building consideration, to the available social or basic infrastructure. They should make their building go handin-hand with the available infrastructural facilities.

\section{REFERENCES}

[1] A. Rapoport, House Form and Culture. New Jersey: Prentice Hall, 1969.

[2] J. E. Spencer and W. L. Thomas, Introducing cultural geography, 2nd ed. New York, Chichester: Wiley, 1978.
[3] K. H. Gholamali and S. El-Din, "Evaluation of the Relationship Between Culture and Traditional Architecture and its Effects on Design Quality Improvement," Volume 11, 0973-4562, pp. 2120 2123, 2016. [Online]. Available: https://silo.tips/download/ evaluation-of-the-relationship-between-culture-and-traditionalarchitecture-and\#

[4] T. Zohreh and B. Sara, "Effective Factors in Shaping the Identity of Architecture," 15(1), 1990-9233, pp. 106-113, 2013.

[5] R. O. Kalilu, "The House as an Encapsulation and Metaphor of Life: New Theoretical Perspectives in Nigerian Architecture in Amole B. (ed): The House in Nigeria," Obafemi Awolowo University, Ile-Ife, Nigeria, 23rd - 24th July, 1997.

[6] L. S. Rikko and D. Gwatau, "The Nigerian architecture: The trend in housing development," 4(5), 2070-1845, pp. 273-278, May. 2011. [Online]. Available: http://www.academicjournals.org/JGRP

[7] A. E. Adeyemi, "Meaning and Relevance in Nigerian Traditional Architecture: The Dialectics of Growth and Change," College Of Science \& Technology, Covenant University, Ota, Nigeria, April 24th, 2008. Accessed: 21st January, 2021. [Online]. Available: http://eprints.covenantuniversity.edu.ng/1367/1/

Prof\%20Adeyemi\%27s\%20Public\%20Lecture\%2012.pdf

[8] F. Stephen and B. S. Kenney, "Cultural Influences on Architecture," Master Thesis, Texas Tech University, Lubbock, Texas., 1994

[9] P. Goetz, Encyclopedia Britannica, 15th ed. Chicago: University of Chicago Press.

[10] J. E. Ahianba, "Cultural Issues in Architecture - Case Study of Esan in Edo State - Nigeria," Journal of Social Sciences, vol. 18, no. 1, pp. 29-43, 2009, doi: 10.1080/09718923.2009.11892664.

[11] A. Rapoport, "Theory, Culture and Housing," Housing, Theory and Society, vol. 17, no. 4, pp. 145-165, 2000, doi: 10.1080/140360900300108573.

[12] Fathy Hassan, Building with People: Tehran University, 1972.

[13] C. O. Osasona, Ed., Traditional Building Forms \& Techniques, Ijebu-Ode, Nigeria: With particular reference to Iwesi, a village on the outskirts of the town, 2007.

[14] African Architecture-African Traditional Architecture. By Susan Denyer. London: Heinemann Educational Books, 1978. Pp. xiv+ 210, illus.£ 8.50 (£ 3.80 paperback). $-L^{\prime} \ldots$, 1980. [Online]. Available: https://www.cambridge.org/core/journals/journal-ofafrican-history/article/african-architecture-african-traditionalarchitecture-by-denyersusan-london-heinemann-educationalbooks-1978-pp-xiv-210-illus-850-380-paperback-larchitecture-enafrique-noire-fassassimasudi-alabipar-paris-maspero-1978-pp185-no-price-stated/64ea58be9e81e2ae71b451a7bb658116

[15] O. P. Agboola and M. S. Zango, "Development of traditional architecture in Nigeria: a case study of Hausa house form," International Journal of African Society Cultures and Traditions, 1(1), 2014. 